\title{
Work transitions as told: A narrative approach to biographical learning
}

\author{
Anders Hallqvist and Lars-Christer Hydén
}

\section{Linköping University Post Print}

\section{Tweet}

N.B.: When citing this work, cite the original article.

This is an electronic version of an article published in:

Anders Hallqvist and Lars-Christer Hydén, Work transitions as told: A narrative approach to biographical learning, 2013, Studies in Continuing Education, (35), 1, 1-16.

Studies in Continuing Education is available online at informaworldTM:

http://dx.doi.org/10.1080/0158037X.2012.712037

Copyright: Taylor \& Francis (Routledge)

http://www.routledge.com/

Postprint available at: Linköping University Electronic Press

http://urn.kb.se/resolve?urn=urn:nbn:se:liu:diva-76636 


\title{
Work transitions as told: A narrative approach to biographical learning
}

\begin{abstract}
In this article we make a contribution to the development of a narrative approach to biographical learning; that is, an approach that considers autobiographical storytelling as a practice through which claims about life history are performed and negotiated. Doing this, we recognize the variety in people's way of making autobiographical narratives. Using insights from narrative theory, we highlight evaluations in narratives and suggest their crucial role in promoting reflexivity. The research area is unemployment, more specifically, work transitions following company restructuring and redundancy supported by outplacement services. Recognizing the learning potential in making autobiographical narratives, the article examines job-loss narratives told by people made redundant. The analysis focuses on strategies used in moments of evaluation. Our findings point to a variety of evaluative strategies and different kinds of reflexivity and, in turn, variation in the potential for biographical learning.
\end{abstract}

\section{Introduction}

In the lifelong learning discourse, new ways of conceptualizing learning have emerged that take into consideration not only skills development but also a wider range of knowledge. A concept that has gained some recognition is biographical learning (Alheit, 1994, Dominicé, 2000, Bron, 2001, Stroobants et al., 2001, Alheit \& Dausien, 2002, Biesta \& Tedder, 2008, Alheit, 2009). Essentially, understood as 'learning about one's life and learning from one’s life' (Biesta \& Tedder, 2007, p. 139), biographical learning is about making sense of one's life course. Contributing to the development of the concept, Tedder and Biesta (2009) have argued that life story telling itself forms an important part of biographical learning processes, saying that narration is not only the outcome of a learning process but 'can be seen as (narrative) learning-in-action' (Tedder \& Biesta, 2009, p. 79). Thus, it is important to look at narration as a practice through which people negotiate meanings and make claims about their life history. 
We would like to argue that some parts of the life stories are more important than others in terms of learning about and from one's own life. Central to all storytelling is the orderering of a number of events into a narrative whole. Of particular importance is the evaluation of these events, something often accomplished by the storyteller through a reflexive moment often found at a particular point or points in the storytelling. Following the path suggested by Tedder and Biesta, in this article we want to highlight the particular moment of evaluation as important for biographical learning since these evaluations display the teller's reflexive relationship to the events that constitute the story and his/her life.

The present paper makes use of stories about work transitions told by people who have been made redundant and are participating in outplacement services. Being made redundant can be viewed as a disruptive event (Becker, 1997) that 'sets human sensemaking in motion' (Buzzanell, 2010, p. 2). Faced with a research interview, people give accounts about this event and how they are responding to the challenge of job loss. Since losing one's job causes a change in a person's life course that he or she did not plan, rather it was effected by one's employer, this can be considered a challenge and a biographical disruption (Becker, 1997) to be coped with through biographical learning.

In a previous study we were able to show a variety of approaches to biographical learning (Hallqvist et al., 2012). The aim of the present paper is to further elaborate on the meaning of biographical learning by using and developing a narrative approach that specifically focuses on the role of self-reflexive narration, informed by Labov's notion of evaluation.

\section{The concept of Biographical Learning}

Biographical learning can be understood as 'learning from one's life and learning about one's life' (Biesta \& Tedder, 2007). Talking about learning from life, biography is viewed as a 'stock of knowledge' (Alheit \& Dausien, 2002, p. 15) that people use when faced by challenges. However, biography could also be seen as the outcome of the learning process when the focus is on new knowledge that is produced. Generally, then, biographical learning is about reclaiming and reconsidering the past in order to cope with challenges of the present.

Reflexivity is central to biographical learning. This is seen in the most cited definition of biographical learing, provided by Alheit and Dausien (2002). According to this definition, biographical learning is 
a self-willed, 'autopoietic' accomplishment on the part of active subjects, in which they reflexively 'organise' their experience in such a way that they also generate personal coherence, identity, a meaning to their life history and a communicable, socially viable lifeworld perspective for guiding their actions (p. 17).

Alheit and Dausien do not discuss potential variations in the way life experiences are organized into life stories and used for biographical learning. Moving in this direction researchers have introduced the notion of 'narrative learning' (Tedder \& Biesta, 2009, Goodson et al., 2010), suggesting a framework for analysing the 'quality' of narratives and narration - in order to 'make sense of the interrelationships between life, narrative and learning'. A distinction is suggested between on the one hand narratives that are mainly descriptive and on the other hand narratives that 'veers more towards analysis and evaluation' (Tedder \& Biesta, 2009, p. 79f, Goodson et al., 2010, p. 13). Besides showing that narration is an important part of biographical learning processes this also indicates the role of evaluation in biographical learning. Taking the narrative perspective on biographical learning one step further, a possible strategy would be to use the notion of evaluation present in narrative theory. Since the moment of evaluation is closely tied to reflexivity it would be fruitful for the study of biographical learning to specifically examine evaluative moments in people's biographical accounts, in order to further explore and understand the learning potential in biographical storytelling.

In his classical writings about narrative, Labov (1972) argued that evaluation is central to narratives and storytelling. In Labov's perspective, the core of a narrative consists of sentences that refer to events and their progression. The progression of these events could be viewed as an answer to the question 'What happened then?' (Labov, 1997). At some moment during the storytelling - Labov argues - the teller has to answer the question 'What's the point telling about this?' (ibid) and thus give the point of the story. In evaluating the events, the storyteller so to speak looks back on the events and relates to them through some kind of evaluative statement.

This evaluation can be accomplished in many different ways (cf. Polanyi, 1989). The teller can position herself differently temporally: from inside the story world by quoting herself or by quoting someone else at the time the events transpired; or the teller can reflect on the events from the here-and-now of the actual telling, stretching back in time. The teller may then either use her own voice or quote someone else evaluating the events. Finally, the teller may either quote someone 
directly creating a dramatic effect, or use indirect speech, retelling what someone thought or said.

In evaluating the events in a story, the teller takes a reflexive stance towards what transpired once. The evaluation is thus of particular interest as a way of understanding how tellers actually use their biographical account(s) as a way of reflecting on their own past. Through the evaluation, the teller reflexively draws a kind of conclusion about those parts of his or her life that have to do with work experience. The teller can use these evaluative conclusions in new life situations; in other words, the evaluations can be used as learned experience.

Previous research in the specific area of job loss and work transitions comprises a few studies that have used an approach similar to the one we suggest. In these studies, researchers analyse interview stories in order to identify various patterns, storylines or plots. For example, Ezzy (2001) finds two main ways of narrating those experiences - in 'romantic' and 'tragic' accounts. In romantic accounts, Ezzy notes that people were able to portray themselves as 'in control' while at the same time denying other people's influence on their decision making, representing an 'individualistic and autonomous view of the self':

the discovery of one's 'real self' is described as a deeply personal and individualistic experience that is explained in terms that emphasise the person's control over their own life (2001, p. 57).

This is explained by considering the ability to make autonomous choices as a condition for self-respect.

Other researchers (Rosenwald \& Wiersma, 1983), studying women's talk about their mid-life career change, have found a widespread 'makeover' tendency, which is rather similar to Ezzy's suggestions regarding 'romantic' job loss narratives. The authors state that individuals initially (the authors call people's accounts a 'press release') tend to portray their life prior to their new career in dark colours, drawing a contrast between their former situation and their new position in life and 'reborn' self. The authors argue that such a rhetoric makes people blind to the social context in which the transition occurred. Portraying the self as an 'autonomous entity' tends to suppress the particularities, i.e. concrete challenges and social relations. Thus, in contributing to a 'critical understanding of the social conditions of personal fulfilment' (p. 215), Rosenwald et al. point to the risks related to a romantic 'make over' rhetoric, while Ezzy acknowledges both positive and 
negative consequences. The authors all agree, however, that such stories tend to portray the self in an slightly idealistic way as autonomous and rather loosely coupled to institutions and social relations (Hallqvist et al., 2012). In contrast, research has shown that non-linear work transitions are to a large extent relational projects (Hallqvist, 2011).

In discussing 'tragic' job loss narratives, Ezzy finds that people position themselves by stressing the power of social forces beyond their control, portraying themselves as 'pushed around by fate and unable to control their lives' (Ezzy, 2001, p. 56). Through this 'victimization' individuals reject failure by focusing on the impact of external forces, while upholding their good intentions and ideals. People are thereby able to maintain integrity and self-esteem while renouncing their responsibility. Referring to research on refugees, Ezzy argues that people are inclined to portray themselves as victims since the victim discourse remains central to the justification of policies. For this reason, the stories are tied up with rhetorical and political objectives.

As the reviewed articles make clear, both Ezzy and Rosenwald et al. move in the direction we propose, pointing out certain recurrent patterns in the interview narrative. However, they do not show whether the storytellers themselves draw the same conclusions. Thus, the authors do not develop a relation between storytelling and learning. We propose that this can be done by paying attention to the moment of evaluation in narratives, since in this particular moment, the storyteller steps forward and takes up a position in relation to events and actions. The evaluations set the storyteller in position to act and provide a resource that can be used as learned experience.

Thus, we suggest that people learn about their life by evaluating biographical events and actions and that different ways of making the evaluation have different potential for biographical learning. Speaking about learning potential we refer to the extent to which the narrative strategy suggest new action options. In this we follow Tedder \& Biesta (2009). Moreover, we suggest that a narrative approach to biographical learning could benefit from using Labov's way of analyzing narratives, taking as point of departure the logic and inner structure of narration and paying attention to the particular moment of evaluation in narratives.

Summing up this brief review, according to Alheit and Dausien (2002) biographical learning is about 'organizing' experiences through biographical accounts in a way 
that enable people to cope with challenges in life. Acknowledging this fundamental insight, other researchers (Tedder \& Biesta, 2009, Goodson et al., 2010) have suggested that narration should be included in the concept, focusing on the rhetorical strategies people use and trying to identify different approaches to biographical storytelling. Moving one step further, we suggest that the narrative evaluation is of special interest in terms of biographical learning.

\section{Method}

Narrative interviews were conducted with people in Sweden who had been made redundant. With the assistance of two outplacement agencies, contact was established with 'mid-life' white-collar men and women who were participating in or had participated in outplacement programmes. Since the challenges connected with work transition would be different for younger people not yet settled in the labour market compared to people somewhat older and more settled in terms of career, social and financial commitments, we selected individuals between the ages of 35 and 55 years with at least eight years in their sector, organization or occupation. Above the upper end of the age range, people close to retirement would tend to be less interested in career change and were therefore similarly not included. Further, we assumed that learning would be more apparent and pronounced among people whose participation in outplacement counselling extended over a longer period, compared to those who quickly found new work. Therefore, all interviewees had been participating in outplacement for more than eight months. The sample included both those who were undergoing training to broaden their professional competence, and those who did not make any such 'expansive' efforts. In this way we ensured variation among individuals, covering both ends of a continuum. In total 23 persons were selected (table 1).

The interview guide was designed to facilitate the production of narratives and to encourage people to tell their stories about their work transition. The initial interview question was: 'I was told that you have been working at (company) but that you lost your job. Would you please tell the story about this and what has happened since then?' To help interviewees remember and develop their narrative, we asked both probing and follow-up questions.

Interviewees were interviewed once each, with the average length of an interview approximately 70 minutes. The first interview was conducted in March 2008 and the last in January 2009. 
Table 1

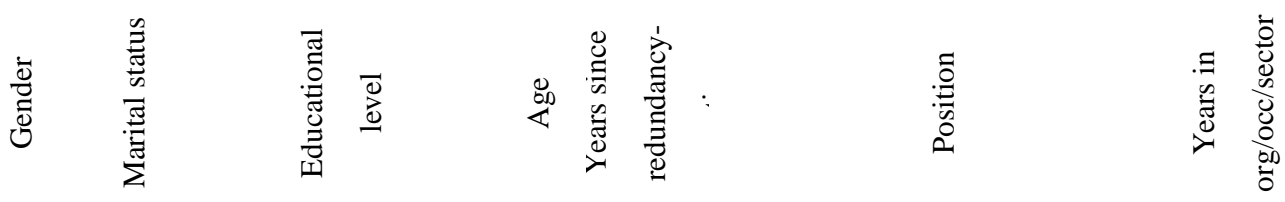

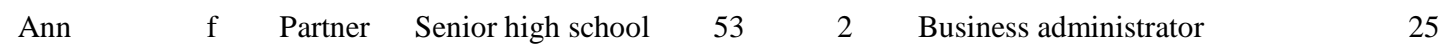

$\begin{array}{lllllll}\text { Britt } & \mathrm{f} & \text { Partner } & \text { Senior high school } & 38 & 5 & \text { Postwoman }\end{array}$

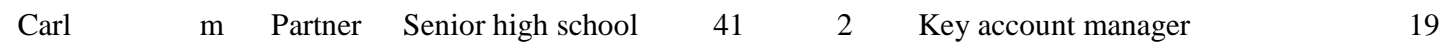

Diana f $\quad$ Single Senior high school $41 \quad 2 \quad$ Assistant nurse/Industrial worker 15/4

$\begin{array}{lllllll}\text { Erik } & \mathrm{m} & \text { Partner } & \begin{array}{c}\text { University } \\ \text { (incomplete) }\end{array} & 45 & 1 & \text { Key account salesman }\end{array}$

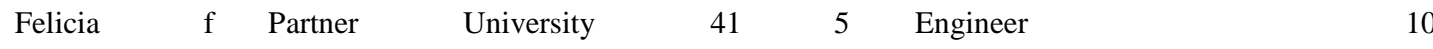

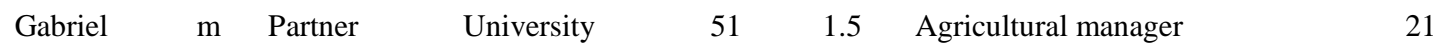

$\begin{array}{llllll}\text { Hanna } & \mathrm{f} & \text { Partner } & \text { Senior high school } & 40 & 1.5\end{array}$

$\begin{array}{lllllll}\text { Isaac } & \mathrm{m} & \text { Partner } & \text { Senior high school } & 49 & 1.5 & \text { Communications specialist }\end{array}$

$\begin{array}{lllllll}\text { Jessica } & \mathrm{f} & \text { Partner } & \text { Senior high school } & 39 & 1.5 & \text { Executive official }\end{array}$

$\begin{array}{lllllll}\text { Katrine } & \mathrm{f} & \text { Partner } & \text { Senior high school } & 50 & 2 & \text { Executive official }\end{array}$

$\begin{array}{lllllll}\text { Louise } & \mathrm{f} & \text { Partner } & \text { Senior high school } & 45 & 1.5 & \text { Purchaser }\end{array}$

$\begin{array}{lllllll}\text { Madelene } & \mathrm{f} & \text { Partner } & \text { University } & 37 & 1 & \text { Sales manager }\end{array}$

$\begin{array}{lllllll}\text { Niklas } & \mathrm{m} & \text { Single } & \begin{array}{c}\text { University } \\ \text { (incomplete) }\end{array} & 42 & 5 & \text { Postman }\end{array}$

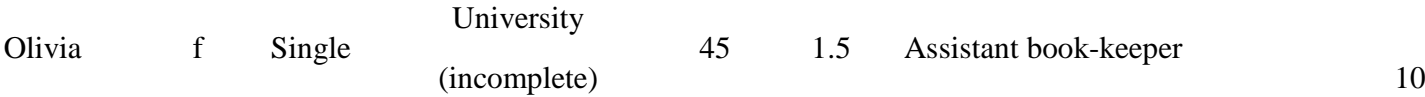

$\begin{array}{lllllll}\text { Paula } & \mathrm{f} & \text { Partner } & \text { Secondary school } & 47 & 3.5 & \text { Restaurant manager }\end{array}$

$\begin{array}{lllllll}\text { Robert } & m & \text { Partner } & \text { Secondary school } & 47 & 2 & \text { Logistician }\end{array}$

$\begin{array}{lllllll}\text { Sara } & \mathrm{f} & \text { Partner } & \text { Senior high school } & 45 & 4 & \text { Assistant nurse }\end{array}$

$\begin{array}{lllllll}\text { Therese } & \text { f } & \text { Partner } & \text { Senior high school } & 44 & 1 & \text { Marketing manager }\end{array}$

$\begin{array}{lllllll}\text { Ulrik } & \mathrm{m} & \text { Partner } & \text { University } & 46 & 3 & \text { Engineer }\end{array}$

$\begin{array}{lllllll}\text { Vendela } & f & \text { Single } & \text { Senior high school } & 44 & 3 & \text { Receptionist }\end{array}$

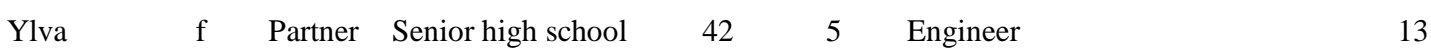

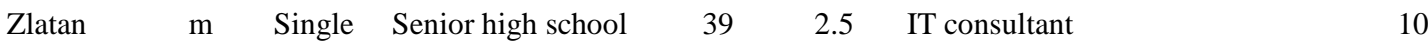


The analysis began with a careful verbatim transcription of the interviews, conducted by the first author. A comparative, case-based analysis (Mishler, 1999) was used to capture the variety of reflexive orientations in the interviews. Those sections of the interviews that could be characterized as evaluative were identified. The evaluative sections are generally bounded in the discourse, marked by for instance a change of tense or the introduction of ' $I$ ' as an evaluator. The evaluations were found either at the end of a narration of specific events, as a reflexive revisiting of the events, or as more general comments on several sets of narrative events. Most of the evaluations occurred in relation to 'choice junctures' (Authors, in press), i.e. crossroads with adherent career decisions. For the purposes of this article, to give an account of the variety of rhetorical strategies used, we selected six excerpts from four interviews. The analysis then proceeded in four further steps: (1) recurrent patterns in the evaluations were identified, (2) those patterns were viewed in relation to the composition of the narrative as a whole, (3) patterns in the interviewees way of narrating were examined, i.e. if different strategies were used and finally (4) the different patterns were related to the overall question of biographical learning.

\section{Findings}

Examining peoples' use of evaluations, we recognized a variety of strategies. For example, there were differences in frequency, verb tense, the position from which the evaluation was made, whether the evaluation was made using direct or indirect speech, and more.

It appeared that the variation in evaluation to some extent related to different modes of reflexivity, which in turn could be regarded as a variety of biographical learning processes. If reflexivity is attained through the praxis of evaluation, since there are different ways of evaluating it follows that people exercise reflexivity is different ways, which in turn leads to various outcomes in terms of learning. As will be shown, the variation occurs not only between individuals but also within individual accounts.

$\underline{\text { Isaac }}$ 
One of the interviewees, here called Isaac, is a 49-year-old communications specialist. Using two narratives from one interview with Isaac, we will show the intra-individual variation and also highlight the relationship between evaluation, reflexivity and learning. Isaac worked for a long time for a large public authority but was made redundant about one and a half years ago (at the time of interview). Describing the job loss as an offence, he has rejected public sector work. Now he wants to change career and start a business of his own. Isaac fosters a dream of becoming an entertainer, lecturer and author. He would also like to set up a variety show with co-workers. In an early phase of the interview, he tells his career narrative in a very matter-of-fact manner:

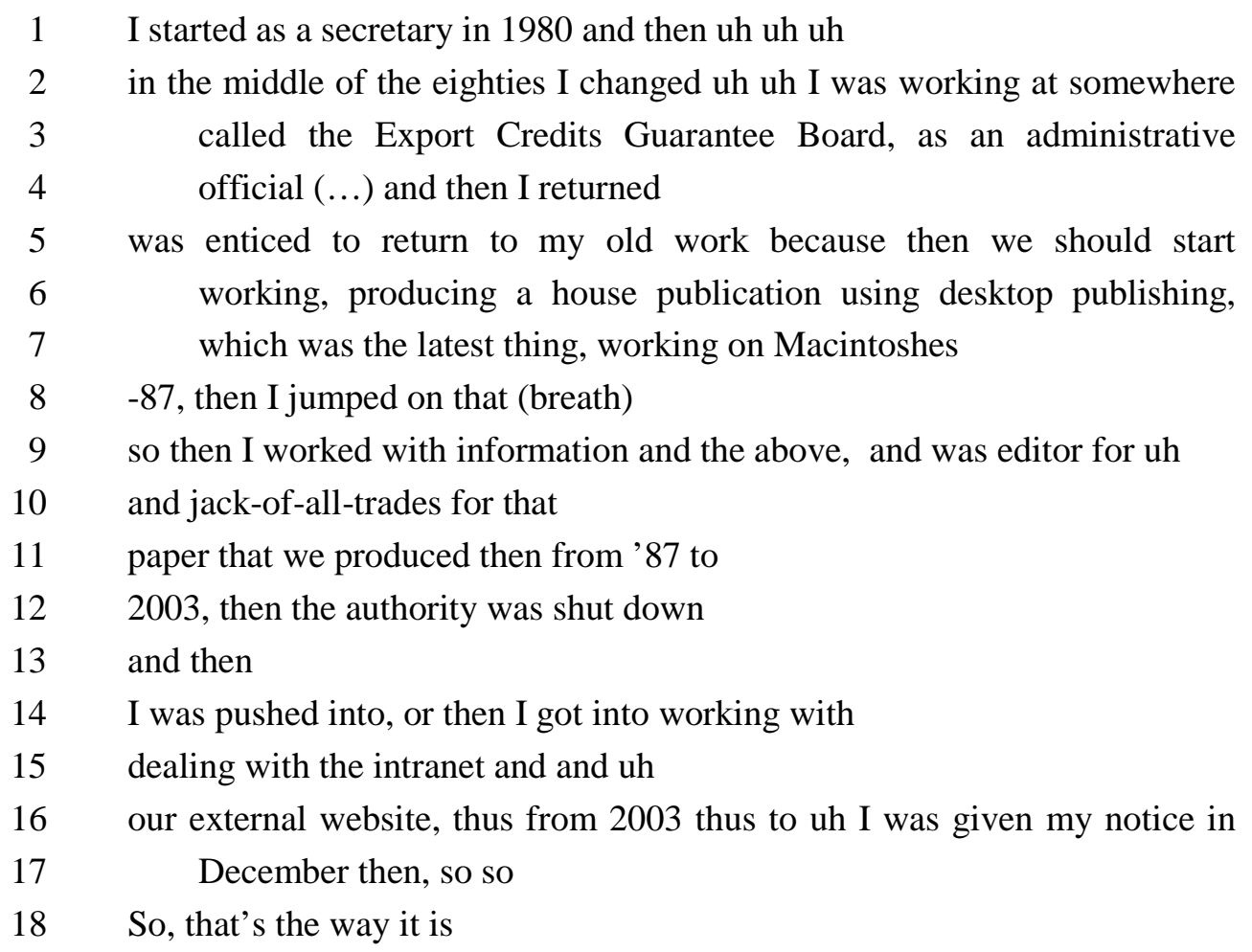

This quotation could be regarded as a 'report' rather than a narrative because Isaac adds event to event without any complicating action - i.e. deviance from the expected - or evaluation of these events. His occupational trajectory including his most recent job loss is presented 'objectively' and the narrative is ended with a simple 'so that's the way it is', without any explicit evaluative statement at all. The possible exception to this non-evaluative stance is the notion of being 'pushed into' dealing with the intranet, through which Isaac positions himself as being somewhat disappointed and perhaps opposed to his managers. Most noteworthy, however, is the account's sober and 'objective' character. No 
conclusions are drawn and no reflexivity exercised. Assuming a possible continuum, this suggests that there are narrative strategies positioned at one end with almost no evaluation at all and with very limited potential for biographical learning.

Further on in the interview, however, Isaac makes extensive evaluative comments. This occurs when the interviewer explicitly mentions that Isaac was given his notice. The speed of talk is then reduced and the statements are interspersed with deep breaths:

1 We became, well it was like, as (long expiration)

2 It was like this, one, uh (p)

3 It is one thing to be given your notice, yeah, now I have uhuh luckily there

$4 \quad$ were three of us who received our notice so one does not need to take

$5 \quad$ it personally then bu' but

One was uh we were given our notice in uh a process of reconstruction, they turned the information section into a communications section, or that was the intention, so we should go for that

$9 \quad$ And then she decided

10 about leaving

11 my manager, who uh uh had handed in her notice thus, she was

12 because she was, became, angry because she was removed from

13 well it can, it doesn't matt...

14 removed from the managerial team so uh, but a final task she did was to 15 conduct an overhaul of the function then

16 And then they decided that we were uh

17 we were classed as

18 we lacked professional competence, uh it was not possible to uh train us

19 and the duties we had uh they would disappear, so and and the new ones to

20 come, those those we would not be able to handle

21 So it was a real slap in the face then when you

22 And the funny thing is that that uh

23 This has been a very drawn out process, because this was in February last 24 year, the $13^{\text {th }}$ we were told about it

25 And uh

26 Well, a lot of such things are popping into my head whil so I, because I 27 have been a ticking bomb in a way, I guess, that first I was just baffled 28 and thought that, and then I want to uh then I do not want to stay, if if I 
If they do not like me, then I don't even want to argue, but then, no then I will do something else

And then the anger has sort of come on subsequently a little. This spring I felt like death warmed up really, it it was, like, tough

In this quotation, the sober, 'objective' interviewee is gone and an engaged person steps forward and gives his assessment of what happened. In fact, right at the beginning of the excerpt, Isaac announces that an evaluation will be provided, by interposing an incomplete distinction saying 'it is one thing to be given your notice' (line 3). The second half of this statement would probably have been 'but another thing how your notice is given by your employer'.

When describing the managers' actions in this passage, he actually takes their position, even though the tense used is past. While he begins the statement by saying 'we were classed as ...' (17), he then changes position and continues from the managers' point of view, saying 'we lacked professional competence, it was not possible to train us ... we would not be able to handle [the new tasks]' (18-20). Thereafter comes the explicit evaluation from the here-and-now position, where Isaac positions himself in relation to those statements and defines the employer's talk as a 'slap in the face' (21). To a large extent, Isaac uses indirect speech and makes his evaluation from the position of here and now, but occasionally he switches to the present tense and talks as if he were still in the midst of the events. Doing this Isaac position himself as being continous emotionally engaged: 'it was a real slap in the face when you, and the funny thing is...' (21-22) and 'if they do not like me, then I don't even want to argue, but then, no then I will do something else' (30-31).

The quotation shows that when evaluating it is possible to focus on (1) the job loss itself, (2) the company's behaviour during the process and (3) the speaker's participation in the event. Thus, the event can be set up within different frameworks. In the excerpt, Isaac is preoccupied with evaluating the managers' role, but it is obvious already from the outset that he intends to evaluate his own role too, saying that he 'was lucky' and that one does not need to 'take it personally'(line 4-5).

Telling the narrative in this way, Isaac learns that the job loss is a real challenge to his self-respect. However, by taking the perspective of the employer and using their rather harsh ways of describing him, the employer emerges as heartless and their statements blunt. 
Later, he returns to reflecting on his own relation to the events. In passing, he comments reflexively on his way of talking about the event in the interview situation, saying that things are 'popping into my head' (26). With this comment, Isaac claims that he is not really in charge of his own reactions and not even of how the narrative is being told. Even though he tells about his future plans, he does not present himself as an autonomous purposeful actor. Most interestingly perhaps, Isaac evaluates his emotional development over the past year: 'first' he was stunned and wanted to leave the company; 'then' this was followed by growing anger. Describing the development, he uses the metaphor of a 'ticking bomb' (27), which indicates controlled rage. It seems that the bomb did not detonate, however: in the last sentences Isaac changes metaphor, stating that last spring he felt like 'death warmed up’ and describing the situation as tough.

In sum, Isaac portrays himself as unsettled and undecided. This is achieved (1) by a shift in the position of evaluation, (2) by claiming that he is not in charge and (3) by reviewing a variety of moods that occurred during the process.

From Isaac's case, we learn that rhetorical strategies vary not only between but also within individuals, and we can identify a narrative strategy positioned at the other end of the mentioned continuum with explicit and extensive evaluations and therefore a greater learning potential. Further, this is achieved not only by taking a marked position in relation to what has happened but also by shifting position recurrently. Doing this, Isaac exercises a pronounced mode of reflexivity and thereby learns a great deal about himself and his development during the transition. This shifting of position is practised in two different ways: by shifting temporal position from past to present and back again, and by shifting social position, from the employer's to his own, and back again. By making his reflexive efforts in this way, he emerges as unsettled and undecided and, thus, continuingly open to further learning.

\section{$\underline{\text { Ann }}$}

The following section from another interview, a 53-year-old business administrator called Ann, points to further distinctions. Using her stories we intend to illustrate another way of shifting perspective and, additionally, point to the praxis of 'interleaving' evaluations throughout the narrative. Faced with the alternative of accepting a lower-skilled job in the organization, Ann decided to try something rather different when she was informed she 
would be made redundant. She moved from Stockholm to a small village in the Swedish countryside to set up a youth hostel with her new husband. In the following excerpt, she describes the events and considerations that ultimately led to a radical occupational transition:

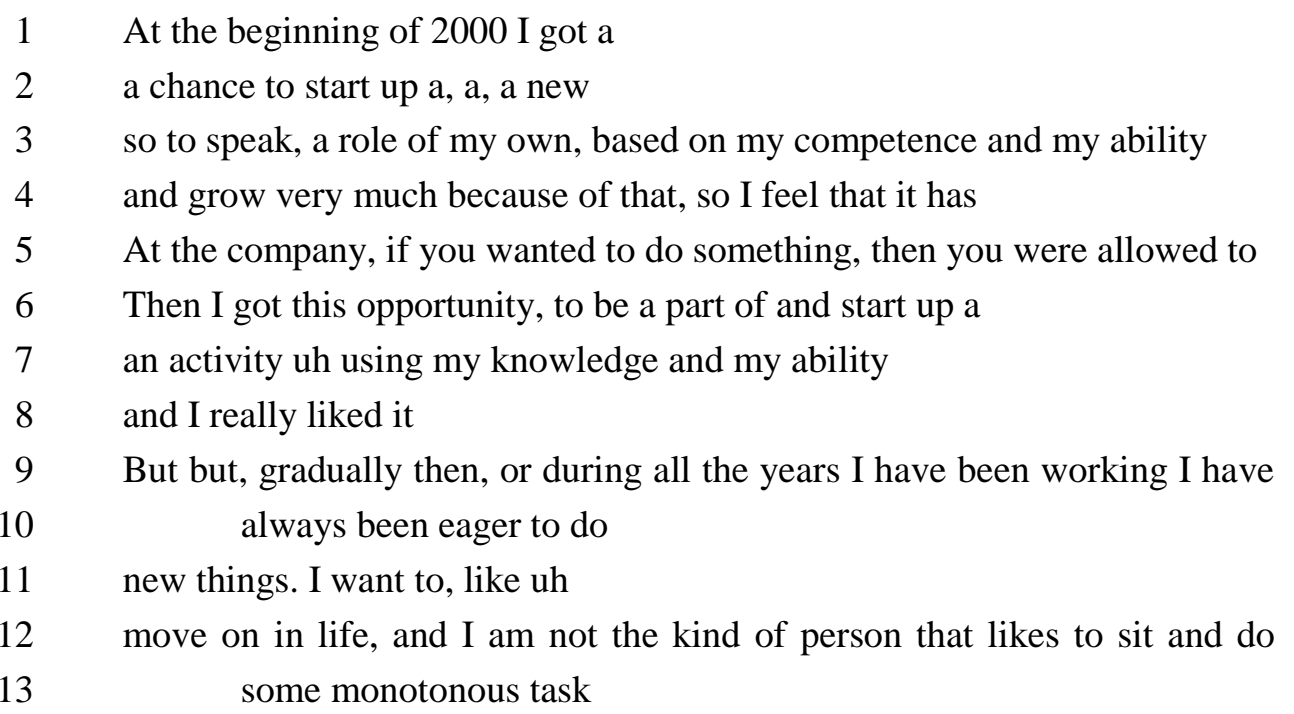

Ann provides an extensive and detailed account of her experiences during the transition: her initial narrative covers several pages and is composed of smaller units each with evaluative statements. Taking a closer look, it appears that Ann's account is interleaved with evaluations. They occupy such a large part of her narrative that the concrete events are almost incidental. In the excerpt here, she mentions one event (lines 1-3), followed by an evaluation focusing on herself (4) and one that focuses on the company (5). She then returns to the event (6-7), attaching a new evaluation (8). Then she mentions a kind of impatience growing during the years at the company (9-10) in order to provide another evaluative statement, first in the perfect tense (10), then in the present tense (11-13). Compared to Isaac's first dense 'report' earlier, Ann's way of storytelling provides a marked contrast. The learning potential in this way of biographical storytelling is probably greater, as there are recurrent comments that centre on the narrator's own intentions. Further, narrating using recurrent evaluations is different to narrative strategies in which a major evaluative comment is given at the end of the story. We will return to this observation in the section below. 
The conclusions drawn in the evaluation centre on Ann herself: her need for selfrealization (4) and her conviction about being a specific type of person, a developmentaloriented type of person (12-13). However, later the perspective becomes wider:

1 Then, because of all the restructuring and the like, which has been happening

2 in society generally, with the stress of that and and people being off sick

3 and and having breakdowns and feeling really bad and suchlike, so I

4 also began to think about

5 how come we are not feeling well?

6 and why do we expose, why do we let, why do we let things go on? Like

7 that.

8 That you just keep on and on and on. And then many people become ill and

9 I have friends and work mates who have been on sick leave for a long time,

10 having difficulty getting back to

11 the people they once were, because of this burnout

12 And I decided, many years ago, that that will not happen to me

In this passage, Ann presents herself as being existentially affected by the event, saying that it has made her begin to think in certain ways. She uses the perfect tense (lines 1-3), and thus refers to previous processes of evaluation (4) by quoting herself (5). Switching to the present tense, Ann points out that those existential deliberations that began a long time ago are still ongoing. Making this evaluation, Ann uses a broad societal framework. Isaac's evaluation above provides a contrast. While Isaac's evaluation narrowly centres on the event of job loss and the process of being made redundant, Ann places the event of restructuring in a wider context, viewing it in relation to what is taking place in society generally. In the same move, however, considerations about Ann's near relations are included in the argument. Doing this, it is not people's financial security that she highlights, but rather identity issues: it is difficult for them to 'get back to the people they once were' (10-11).

Thus, in this excerpt the event of job loss is not in focus, nor are her employer's actions in the process. Rather, there is an attempt or at least an impulse to evaluate society generally. Thus, Ann's way of evaluating processes of company restructuring differs radically from ways in which a job loss is evaluated in individualistic-materialistic terms.

The societal framework does not counter the existential challenge, however; rather it makes it even more intense. The evaluation centres on existential issues with adherent 
individual choices: the central question concerns why 'we' let things happen without doing anything about it. Thus, Ann makes an argument for human agency, choice and determination: 'I made a decision ... many years ago ...' (12), presenting herself somewhat idealistically as an autonomous agent.

Through her way of evaluating, Ann exercises reflexivity by placing the event of job loss within different frameworks. By shifting between political, social and existential frames of reference, she develops knowledge that has an impact on the process of decision making. While Isaac shifts between taking his own position and his employer's when evaluating the process of being made redundant, Ann does not leave her own voice or position, and thus she does not play with taking different roles. Instead she shifts framework from political to existential, to a moral or a social framework, though from the same position. While Isaac appears unsettled and undecided, Ann emerges as agential, with a firm belief that she can act to change her situation, presenting herself as autonomous and determined.

\section{Gabriel}

In the following excerpt, from the last lines of an extensive narrative told by Gabriel, a 51year-old agricultural manager, questions are raised concerning agency, strength and the need for social support:

1 reflecting on all this

2 uh one has the feeling, I have thought this many times because I have never

3 been out of work

4 I am 51 years old and have never been unemployed

5 Then one's opinion goes like this:

6 'People are unemployed. There are jobs, you only have to take a job, that's all

7 you have to do', like that

8 'It's ridiculous'.

9 But I have understood that

10 It is a little like in the health sector, if you are not healthy and strong, then you

11 will not be able to carry on

12 Because today it has come to this: you need to get yourself a sponsor

13 You need to get yourself someone who

14 Yes

15 No one gives you anything

16 That is my view of it. 
Reminiscent of Ann above, Gabriel makes general statements about society, the vulnerability of the individual and the work climate today which is cold and hard. He compares this with conditions in the health sector, concluding that you 'have to be healthy and strong' to be able to carry on. In fact, previously Gabriel talked about himself as an 'energetic' person, an architect of his own fortune while emphasizing the shortcomings of the public employment service (which has suffered severe cuts), the career counsellors at the university (who are 'available by telephone between 9 and 9.15 on Thursdays') and those at the outplacement agency (who are not 'up to date'). It is paradoxical that, while talking about the need for social support, Gabriel at the same time claims that 'no one gives you anything'. If you need support but no one will give you any, the situation seems almost hopeless. Probably, however, the point is that you cannot wait for others to come to your aid; rather, you have to obtain their help by actively asking for it. Examining the content of the evaluation, it thus centres on the relation between the individual and society, highlighting the scarcity of the support offered, and the need to be active in requesting support from others. This conviction is then turned into a recommendation that people should get themselves a 'sponsor'.

In contrast to the quotations from Ann above, in Gabriel's narrative the evaluation is held back until the closure of his extensive account. Through this particular move, the forthcoming statements gain strong emphasis, appearing as a kind of major conclusion or 'lessons learned'. The character of speaking 'ex cathedra' is accentuated even more by the explicit and marked introduction: 'and reflecting on all this ...', the claim that he has thought this 'many times' and by highlighting his considerable age. Moreover, Gabriel claims to know things that are hidden to most people. Using the indefinite pronoun (line 5) followed by a quotation, Gabriel announces and identifies with a general opinion. Then, by referring to a kind of revelatory knowledge and a change in view, he disassociates himself from this opinion, making a contrast between people who know from personal experience what it is to be unemployed and people who merely have prejudices.

While Gabriel recognizes that there are different positions and opinions regarding being unemployed, compared to Isaac who tries different social and temporal positions and uses them descriptively, without really choosing one, Gabriel is clear about his own position, what change he has undergone, and what knowledge is valid. Gabriel's evaluation is from the here-and-now position, and he seems to be 'settled' in the sense that his deliberations have come to an end. In contrast, Isaac and Ann continuously reflect about themselves and 
the events, drawing no definitive conclusions. Further, we can note that Gabriel's evaluation is expressed in general terms, and centres not on him as unemployed but around unemployment as a general societal issue.

It should not be a surprise, then, that he ends up providing recommendations and requirements, using the imperative mood, talking about what 'you' need to do. Here Gabriel uses the second person pronoun but as an indefinite pronoun, which is why the recommendations appear to be generalizable. Thus, even though Gabriel provides an autobiographical narrative, the lessons learned concern not primarily his own life, rather they are general conclusions, seemingly applicable to anyone in the same situation.

\section{Olivia}

Our final example, selected from an interview with a 45-year-old assistant bookkeeper called Olivia, provides in a sense the opposite of Gabriel's strategy in evaluating, since the evaluation is not really made explicit but is almost hidden:

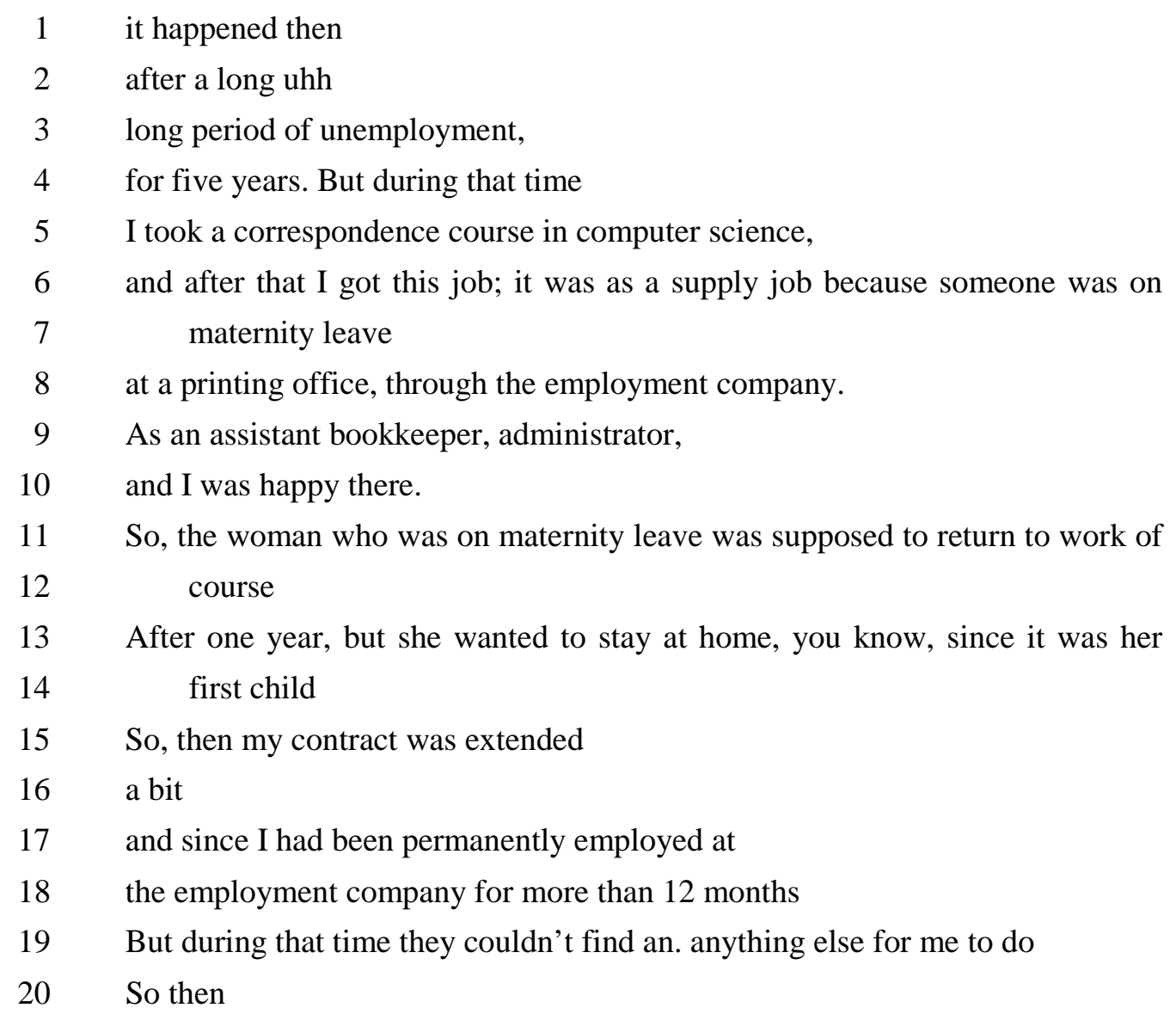


23 And the period after that

24 then

25 I thought it would be a straightforward matter to find a job, when you have

26 been employed for a longer period and the job market seemed OK for

27 people with my qualifications in finance

When telling a her work transition, Olivia's most obvious evaluation does not concern the event of job loss but rather her job satisfaction ('I was happy there', line 10). There is, however, a cautious and almost hidden evaluation of the job loss, expressed in the adverb 'of course' (21) through which Olivia accepts, seemingly without protest, her employer's decision to let her go and, moreover, asks for the listener's support or approval for this conciliatory conclusion. Thus, she does not make the evaluation explicitly, but refers to a supposed self-evident matter of fact based on the previous sentence ‘they couldn't find anything else for me to do' (19). At the end of the excerpt, Olivia makes another evaluation when she says that she thought it would be easy to find a new job. However, she does not finish her train of thought: she does not add 'but it has not been easy to find a job'. Rather the interviewee lets the interviewer draw this obviously self-evident conclusion himself. By letting her evaluations come to effect implicitly, Olivia lays claim to the listener's tacit approval. However, in doing this she disclaims her opportunity to use her own voice and, thereby, she disclaims the opportunity to make her own knowledge about the event of job loss. This strategy of making 'implicit' evaluations can be viewed in relation to another observation. In the excerpt, Olivia makes her evaluations from within the story; thus she does not make any evaluative comment from her position here and now. This probably affects what knowledge is developed. In contrast, in Gabriel's excerpts the evaluative comments are made only from the position of here and now.

Further, while in the previous excerpt Gabriel underscored the change he had undergone, by talking about an 'insight' that made him change his mind, and while Ann and Isaac continually reflected on themselves in relation to the event of their job loss, Olivia's account suggests that any re-evaluation of what happened is not an option for her, rather she considers the evaluation made as continuously valid. Thus, she does not seem to learn very much from her storytelling. The learning potential in 
Ann's and Isaac's rhetorical strategies seems to be greater. And in Gabriel's, too, even though he does not - in the same manner as Isaac and Ann - keep 'the reflexively available reference to self fundamentally open' (Alheit, 1994, p. 289) but closes the case, so to speak, after having made his reconsideration.

\section{Discussion}

The variation in evaluative strategies we have highlighted suggest that there are different kinds of reflexive efforts, which, in turn, are related to different modes of biographical learning. This variation is not only found between individuals but also 'within' individuals, that is, one individual may use a variety of strategies. As the case of Isaac shows, a person can give different narratives on different occasions. Thus, it should not be considered a competence that people either do or do not possess, residing within an individual; rather it is related to situation: time, space, audience and the position in the overall narrative.

Assuming a continuum ranging from no evaluation or 'weak' modes of evaluation to 'marked' or 'strong' ones, it seems like the latter promote a 'pronounced' (Hallqvist et al., 2012) mode of biographical learning. The strategy of shifting perspective on life events is probably also productive in this respect, often accomplished by the use of different social and temporal positions and by viewing events within different frameworks.

The evaluative strategies employed also have an impact on whether the individual portrays him- or herself as in charge of the process or determined by other, often external forces (e.g. society, market, companies). Making implicit evaluations is probably a precarious undertaking since the teller thereby disclaims a chance to form his or her own knowledge or opinion on what has happened. On the other hand, as the case of Ann has shown, certain strategies seem to confirm the observation of an idealistic tendency in career-decision narratives, presenting the self as an autonomous entity (Rosenwald \& Wiersma, 1983, Ezzy, 2000, Ezzy, 2001).

Rosenwald \& Wiersma (Rosenwald \& Wiersma, 1983) point to an individualistic tendency and a kind of 'make over rhetoric' in career decision narratives portraying 
individuals as autonomous and the transition as a discovery of one's 'real self'. This observation is confirmed by Ezzy (2000, 2001); however, Ezzy is less pessimistic since he regards people's ability to portray themselves as being in 'in control' as a condition for self-respect' (2001, pp. 56-57). The relation between a transition as told and a transition as lived is thus important to acknowledge. People making images of themselves and their career with no relation to reality is not something desirable. Hallqvist et al. (2012), have proposed an 'idealistic' mode of biographical learning, by which people narrate a contrast between their life preceding the transition and their new career, but without enabling them to act and Alheit (1994) makes normative statements about the interrelation between sense making and social action, saying that 'structure and subjectivity form an important combination' (p. 288), suggesting that the concept of biographical learning makes it possible to establish this important 'link' between 'stories and structures' (Alheit, 2005).

Our findings show that the presentation of an autonomous self is related to particular evaluative strategies. Further, we have (in the case of Isaac) highlighted that certain strategies seem to be related to being undecided or hesitant, while others make people 'close the case' and take action. Nevertheless, the suggestions are tentative and further elaboration is necessary in order to understand the complex relation between evaluative strategies, reflexivity and action. 


\section{References}

Alheit, P. (1994) 'The 'biographical question' as a challenge to adult education', International Review of Education, Vol. 40 No. 3, pp. 283-298.

Alheit, P. (2005) 'Stories and structures: An essay on historical times, narratives and their hidden impact on adult learning', Studies in the Education of Adults, Vol. 37 No. 2, pp. 201-212.

Alheit, P. (2009) 'Biographical learning - within the new lifelong learning discourse', in K. Illeris (ed.) Contemporary theories of learning: Learning theorists ... In their own words. London: Routledge.

Alheit, P. and Dausien, B. (2002) 'The double face of lifelong learning: Two analytical perspectives on a silent revolution', Studies in the Education of Adults, Vol. 34 No. 1, pp. 3-22.

Authors (in press) 'Learning in occupational transitions - a study of the process following job loss', WORK: A Journal of Prevention Assessment, and

Rehabilitation., Vol. No.

Becker, G. (1997) Disrupted lives: How people create meaning in a chaotic world. Berkeley, CA, University of California.

Biesta, G. and Tedder, M. (2007) 'Agency and learning in the life course: Towards an ecological perspective', Studies in the Education of Adults, Vol. 39 No. 2, pp. 132-149.

Biesta, G. and Tedder, M. (2008) Learning from life in the learning economy: The role of narrative, paper presented at the 38th Annual Conference of Scutrea, City.

Bron, A. (2001) 'Civil society and biographical learning', in M. Schemmann \& M. Bron (eds.) Adult education and democratic citizenship IV, Krakow: Impuls.

Buzzanell, P. M. (2010) 'Resilience: Talking, resisting, and imagining new normalcies into being', Journal of Communication, Vol. 60 No. 1, pp. 1-14.

Dominicé, P. (2000) Learning from our lives. San Francisco, Jossey-Bass.

Ezzy, D. (2000) 'Fate and agency in job loss narratives', Qualitative Sociology, Vol. 23 No. 1, pp. 121-134.

Ezzy, D. (2001) Narrating unemployment. Aldershot, Ashgate.

Goodson, I. F., Biesta, G., Tedder, M. and Adair, N. (2010) Narrative learning. London, Routledge.

Hallqvist, A. (2011) 'Occupational transitions as a relational project', Studies in Continuing Education, Vol. No., pp. 1-16.

Hallqvist, A., Ellstrom, P. E. and Hyden, L. C. (2012) 'The many faces of biographical learning', Studies in the Education of Adults, Vol. 44 No. 1, pp. 70-84.

Labov, W. (1997) 'Some further steps in narrative analysis', Journal of narrative and life history, Vol. 7 No., pp. 395-415.

Mishler, E. G. (1999) Storylines: Craftartists' narratives of identity. Cambridge, Harvard University Press.

Polanyi, L. (1989) Telling the american story: A structural and cultural analysis of conversational storytelling. Cambridge, MA, The MIT Press.

Rosenwald, G. C. and Wiersma, J. (1983) 'Women, career changes, and the new self. An analysis of rhetoric', Psychiatry, Vol. 46 No. 3, p 213. 
Stroobants, V., Jans, M. and Wildemeersch, D. (2001) 'Making sense of learning for work. Towards a framework of transitional learning', International Journal of Lifelong Education, 20, Vol. 1 No. 2, pp. 114-126.

Tedder, M. and Biesta, G. (2009) 'Biography, transition and learning in the lifecourse. The role of narrative.', in J. Field, J. Gallacher \& R. Ingram (eds.) Researching transitions in lifelong learning. Abingdon: Routledge. 